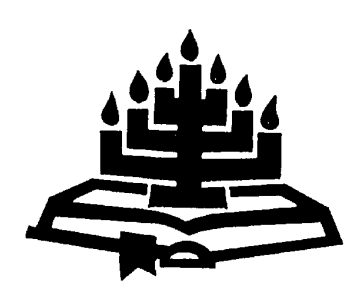

\title{
Die spiritualiteit van die bedienaar met verwysing na sy toerustingstaak
}

\author{
C.J.H. Venter \\ Vakgroep Praktiese Teologie \\ Skool vir Kerkwetenskappe \\ Potchefstroomse Universiteit vir $\mathrm{CHO}$ \\ POTCHEFSTROOM \\ E-pos:dmscjhv@puknet.puk.ac.za
}

\begin{abstract}
The spirituality of the minister with reference to his task to equip

Although considerable practical-theological research has already been undertaken in the field of spirituality, certain issues still need further investigation. One of the main issues in this regard is the interrelationship between the spirituality of the minister and that of the congregation and thus the task of equipping the congregation to an intensified spiritual life. Key issues dealt with in this article are the concept of spirituality in the Pastoral Epistles, a pneumatological point of departure in investigating the spirituality of the minister, the actual source of his spirituality, spirituality and charisma, the interrelationship between the spirituality of the minister and the spirituality of the congregation. In this regard attention is also paid to the act of exercising spirituality by way of prayer, reading and applying Scripture in the minister's personal life. In conclusion the minister's act of self-investigation is also highlighted. In this regard the need for continuous growth in personal spirituality as a prerequisite for equipping the congregation for their spiritual life is justified and emphasized by relevant Scriptural passages.
\end{abstract}

\section{Inleiding}

In besinning op die gebied van die Praktiese Teologie is ' $n$ verskuiwing besig om tans plaas te vind. Die afgelope vyftien tot twintig jaar is besinning in ' $\mathrm{n}$ groot mate gerig op die nadere fundering van gemeentebou (Venter, 1986:1-10; Nel, 1994:1-60), op die ontwikkeling van 'n visie, missie en doelwitte in gemeentebou (Nel, 1994:125-147; Van der Merwe, 1995:37-48). So kom ook prediking in die ekstensiewe opbou in besinning aan die orde (Oh, 
1998:124-158), en ook die voortgaande toerusting van die gemeente tot opbou (Kanagaraj, 1997:326-331).

Tans verskuif die fokus in Prakties-Teologiese besinning al meer na die terrein van die sogenaamde spiritualiteit, veral van die bedienaar. (In punt twee van hierdie artikel word die term spiritualiteit afgegrens en word nader gedefinieer hoe dié term in hierdie artikel gebruik word). Hulse (1986:62-90), Houston (1991:179-197) en Venter (1998) betrek die fundering en praktyk van die spiritualiteit van die bedienaar in hulle navorsing. Clements (1998:10-17) en Kim (1997:1-10) klem lê op die belang van die bedienaar se spiritualiteit vir sy prediking as toerusting, terwyl Tidball (1997:120-121) fokus op die belang van die bedienaar se spiritualiteit vir sy herderlike werk (vergelyk ook Lartey, 1997:113-123). Spiritualiteit kom ook wetenskaplik aan die orde sover dit die liturgiese belewing van bedienaar en gemeente raak (Witvliet, 1997:273-298). Ook die vraagstuk van spiritualiteit en die transformerende krag van aanbidding word opnuut ondersoek (Leithart, 1997:27-34).

Hierdie hernude fokus op spiritualiteit en die wetenskaplike besinning daaroor sal deur studie van die oorsake daarvan nog in 'n helderder perspektief geplaas moet word. Dat die klem egter tans sterker as voorheen val op die dimensies van ervaring (Brink, 1997:398; Drane, 1997:339-340; vgl. ook Bair, 1995:75) en op toerusting tot aktiewer deelhê en deelname van die gemeente aan liturgiese elemente (Brink, 1997:399), is 'n gegewe feit, tot so 'n mate dat in sommige literatuur al sprake is van 'n verbruikershermeneutiek (vgl. Bartholomew, 1998:91-114).

Wie die wetenskaplike besinning oor spiritualiteit nagaan, merk in die huidige besinning tog tans bepaalde leemtes op. Van hierdie leemtes kan só verwoord word: wat is die verhouding tussen die persoonlike spiritualiteit van die bedienaar en dié van die gemeente? Kan 'n bedienaar 'n dieper spiritualiteit as sy eie van die gemeente verwag? Op watter wyses kan die bedienaar - as instrument van die Heilige Gees - die toerusting tot verdiepte spiritualiteit van die gemeente aanpak? Watter taak het die gemeente in die verdieping van die spiritualiteit van die bedienaar?

\section{2. 'n Werksdefinisie van spiritualiteit}

Voordat die verdere aanloop van hierdie artikel in die visier gestel word, moet eers 'n werksdefinisie gebied word van wat in hierdie artikel onder spiritualiteit verstaan word. In die konteks van hierdie artikel kan nie wyd op 'n verskeidenheid van definisies en verbandhoudende aspekte met spiritualiteit ingegaan word nie. Eerder sal 'n bepaalde lyn in die omskrywing van spiritualiteit benadruk en nader belig word. Hierin moet egter 'n duidelike voorwaarde gestel word. Spiritualiteit hou nie in 'n skeiding tussen natuur en genade nie, of dat eensydig net gefokus word op die geestelike lewe van die bedienaar nie. So 'n standpunt 
sou reduksionisties wees. Die Bybel sien die mens altyd in geheel of as eenheid, al word bepaalde dimensies van daardie geheel dan deur sekere Bybelse begrippe (gees, liggaam) belig.

Meer outeurs gebruik as omskrywing van spiritualiteit die uitdrukking: 'n lewe coram Deo (Velema, 1992:28; Louw, 1997:16-17). Hierdie omskrywing hou in dat die lewe van 'n gelowige (i.c. bedienaar) in al sy fasette 'n lewe voor die oë van God is. Hulse (1986:65) verwoord spiritualiteit dan as “... that constant culture of the inward life of holiness before God and for God, which in turn is applied to all other spheres of life and practice".

Vir hierdie artikel word onder spiritualiteit dan verstaan die lewe van die bedienaar en gemeente - as totale lewe - coram Deo. Uiteraard sal so 'n omskrywing verband hou met Bybelse uitdrukkings soos godsvrug, vroomheid, geloof, liefde, selfbeheersing, heiligheid en meer toepaslike begrippe wat ook in die Nuwe Testament voorkom - in besonder in die Pastorale Briewe (vergelyk ook punt 5).

\section{Metodiese opmerkings}

Hierdie artikel het veral as doel 'n nadere ontginning van gegewens oor spiritualiteit met die oog op die vorming van basisteorieë in die vakgebied Praktiese Teologie. Vir hierdie artikel sal veral gefokus word op die ontginning van gegewens uit die Pastorale Briewe en in 'n mindere mate uit die Brief aan die Efesiërs. Die motivering hiervoor is dat die Pastorale Briewe van die mees sentrale openbaring oor die bedienaar, sy bediening en sy spiritualiteit bevat soos dit in die plaaslike kerk neerslag vind (Stott, 1996:37 e.v.). In Efesiërs word voorts in hoofsaak gehandel oor die kerk as liggaam van Christus, die Hoof (Perkins, 1997:29).

Deur analise en interpretasie sal die toepaslike materiaal gekeur en gerangskik word om in te pas in die besondere opset en hoek van benadering vir hierdie artikel.

\section{Sentrale hipotese}

Die sentrale hipotese is dat die Pastorale Briewe en Efesiërs toepaslike materiaal bevat wat nader ontgin behoort te word met as verwagte uitkoms verdere vorming van basisteorieë oor die spiritualiteit van die bedienaar.

\section{Die konsep spiritualiteit in die Pastorale Briewe}

Dit is opvallend dat in vyf gedeeltes in die Pastorale Briewe klaarblyklik gehandel word oor spiritualiteit en verbandhoudende elemente. In drie gedeeltes, 1 Timoteus 4:7-8, 1 Timoteus 6:11 en 2 Timoteus 3:12 word die uitdrukking 
eusebeia-eusebõs gebruik. In een gedeelte, 1 Timoteus 4:12, word hagneia gebruik en in 2 Timoteus 1:9 word die begrip hagios gebruik.

Vir die nadere omlyning van spiritualiteit in die Pastorale Briewe is dit vooraf nodig om die begrippe eusebeia, hagneia en hagios af te grens.

- Die begrip eusebeia het die nuansering van toewyding, eerbied (piety) en meer in die algemeen die nuansering van godvresend en ook van godsdiens (Fiedler, 1991:84-85). Dit is van belang dat die uitdrukking eusebeia in die Pastorale Briewe 'n besliste Christologiese gerigtheid veronderstel in die wyse waarop geleef word, "in the service of God's universal purposes eusebeia has as its goal the fundamental Christological values" (Fiedler, 1991:84-85).

Stott (1967:63) pas hierdie nuanse van spiritualiteit op die prediker toe as hy stel dat die persoonlike ervaring van God se genade in Christus die " ... first and indispensable mark of the Christian witness" is.

- Die uitdrukking hagneia kom voor in 1 Timoteus 4:12 met die konnotasie van opregte (suiwer) toewyding, “... purity (as) the perfect union of the congregation with Christ" (Balz, 1990:22). In die Pastorale Briewe word die begrip hagneia meermale saam met verbandhoudende uitdrukkings soos lewenswandel, liefde en geloof gebruik om suiwer en opregte toewyding aan God te verwoord.

- Die begrip hagios kom in verband met die persoonlike toewyding van die bedienaar in 2 Timoteus 1:9 voor.

Waar gelowiges en bedienaars heilig genoem word, word heilig gebruik in die sin van "... called out of the world about them into the presence of God as a holy people ... This holiness manifests itself in pure and undefiled conduct. The holiness of the Christian life derives from the holiness of God" (Balz, 1990:17). In die lewe van die bedienaar kom die dimensie van heilig wees na vore in die beoefening van heiligheid - nie as trappe in die voortgang tot religieus-etiese perfeksionisme nie - maar as 'n deur tot die beoefening van gemeenskap met God.

Uit die nagaan van hierdie drie begrippe uit die Pastorale Briewe word die volgende afleidings nou gemaak:

- Spiritualiteit veronderstel 'n lewe van toewyding aan God op grond van die heilswerk van Christus.

- Die persoonlike toewyding van die bedienaar aan God moet opreg (suiwer, sonder bymotiewe) wees, in ooreenstemming met die roeping van die gemeente om haarself as een liggaam aan die Here toe te wy. 
- Toewyding as 'n heilige en afgesonderde lewe wortel in die heiligheid van God.

- Heiligheid as spiritualiteit dui nie op etiese perfeksionisme nie, maar op die beoefening van gemeenskap met die heilige God.

\section{Die pneumatologiese vertrekpunt vir die spiritualiteit van die bedienaar}

Uit bogenoemde aanduiding dat spiritualiteit in verband gebring behoort te word met veral uitdrukkings soos toewyding, suiwerheid (opregtheid) en heiligheid, kom die vraag na die oorsprong en funksionering van spiritualiteit nou na vore.

Dit is van kardinale belang dat vir die ontstaan en beoefening van spiritualiteit deur die bedienaar nie 'n psigologiese of mistieke vertrekpunt geneem moet word nie, maar wel 'n pneumatologiese vertrekpunt.

In die Pastorale Briewe is op vyf plekke eksplisiet sprake van die Heilige Gees, naamlik in 1 Timoteus 4:1; 2 Timoteus 1:7 en 14, en Titus 3:5 en 6. In die laaste vier uitsprake word die werk van die Heilige Gees op bepaalde vlakke in verband met spiritualiteit of bepalende aspekte vir spiritualiteit gebring.

\section{- Die oorsprong van spiritualiteit}

In Titus 3:4 word gestel dat God ons vir eens en vir altyd (aoristus) verlos het op grond van sy eie ontferming. Aksie van die kant van die mens is by hierdie ontferming van God uitgesluit. Hierdie verlossing van God word ons deel (letterlik) "... deur die bad van die wedergeboorte". Wedergeboorte word hier voorgestel as die afwassing van die sonde. Verlossing word verder ons deel "deur die nuutmakende Heilige Gees". Die Heilige Gees maak van die mense in sonde nuwe mense. Meer nog: die Heilige Gees is dit "... wat ryklik op julle uitgegiet is deur Jesus Christus ..." (vers 6). En nou is dit juis hierdie Gees wat die spiritualiteitsdimensies van "vryspraak, erfgename en die ewige lewe" (vers 7) 'n werklikheid maak in die lewe van die gemeente en van die bedienaar.

Sowel die oorsprong as die voortgang van spiritualiteit in die lewe van die bedienaar moet dus gefundeer word in die werk van die Heilige Gees.

\section{- Spiritualiteit, Gees en charisma}

In die Pastorale Briewe is twee maal sprake van die charisma wat Timoteus ontvang het (1 Timoteus 4:14 en 2 Timoteus 1:6). In die eerste geval word Timoteus opgeroep om nie sy charisma te verwaarloos nie en in die tweede geval om die charisma aan te wakker. Charisma en spiritualiteit hoort onlosmaaklik byeen, juis omdat dit dieselfde Gees is wat albei in 'n bedienaar werk. Nie net ten opsigte van die oorsprong nie, maar ook in die aanwakker van die charisma staan die werk van die Heilige Gees sentraal. Die opdrag om aan te 
wakker kom net een keer in die Nuwe Testament voor en dit is hier in

2 Timoteus 1:6. Ontleed in sy samestellende dele ana (weer) en zo (lewe) en purein (vuur) hou hierdie opdrag dus in om weer (opnuut) lewe in die vuur van die charisma te blaas. Dat die werk van die Heilige Gees hierin sentraal staan, word bevestig deur die feit dat die Heilige Gees meermale in die Nuwe Testament enersyds in verband met lewe en andersyds in verband met vuur gebruik word (byvoorbeeld Johannes 6:63; Romeine 8:1; Handelinge 2:3; 1 Tessalonisense 5:19).

Met bostaande uiteensetting kom ons op die terrein van die wisselwerking tussen bedieningsgawe en spiritualiteit in die lewe en toerustingswerk van die bedienaar. Waar bedieningsgawes nie gebruik en aangewakker word nie, tree verflouing in, ook in die bedienaar se belewing van sy eie spiritualiteit.

\section{- Spiritualiteit en die Gees as gewer van krag, liefde en selfbeheersing (2 Timoteus 1:7)}

Hierdie vers (2 Tim. 1:7) volg direk na die opdrag aan Timoteus om sy ampsgawe aan te wakker. 'n Teenstelling word hier gemaak tussen lafhartigheid enersyds en krag, liefde en selfbeheersing andersyds. Letterlik word hier gestel: "God het ons nie 'n Gees van vreesagtigheid gegee nie, maar van krag, liefde en selfbeheersing". Hierdie laaste drie - krag, liefde en selfbeheersing - is kernelemente van die spiritualiteit van 'n bedienaar. In Galasiërs 5:22 word liefde genoem as eerste (en grondliggende) aspek van die vrug van die Gees in 'n gelowige se lewe. Selfbeheersing word laaste (en klimakties) genoem as "hoogste" openbaring van die vrug van die Gees in die gelowige se lewe. Krag word ook dikwels in die Nuwe Testament in verband met die Heilige Gees gebring.

Samevattend kan dus hier gestel word dat die spiritualiteit van die bedienaar in sy ontstaan en funksionering in die Heilige Gees en sy werk gefundeer moet word. Dieselfde Gees wat die spiritualiteit gee, gee ook die charisma aan die bedienaar. Verwaarlosing van die charisma lei noodwendig tot verwaarlosing van spiritualiteit omdat albei bewerk word die Gees. Die Heilige Gees staan ook sentraal in die gee van krag, liefde en selfbeheersing as onmisbare elemente in die spiritualiteit van die bedienaar en in sy toerusting van die gemeente.

\section{Die wisselwerking tussen die spiritualiteit van die bedienaar en die spiritualiteit van die gemeente}

1 Timoteus 1:6-8 word nou nader verken met die oog op moontlike toepaslike gegewens vir hierdie onderafdeling.

In die 1983 Afrikaanse vertaling van die Bybel word vers 6 soos volg weergegee: 
As jy hierdie dinge aan die broers voorhou, sal jy 'n goeie dienaar van Christus Jesus wees wat jouself voed met die woorde van die geloof en die goeie leer waarvan jy 'n aanhanger geword het.

Die direkte verband waarbinne 1 Timoteus 4:6 staan, is belangrik. Die vers word voorafgegaan deur 'n uiteensetting hoe Timoteus moet optree teenoor dwaalleraars wat mense verbied om sekere soorte kos te eet. Paulus sluit sy konklusie oor die eet van kos af met: "Niks wat met die danksegging ontvang word, is verwerplik nie, want dit word deur die woord van God en deur die gebed geheilig" (vers 5). Voordat die skrywer oorgaan om aan Timoteus die wisselwerking tussen die spiritualiteit van die bedienaar en die gemeente te behandel, beklemtoon hy eers twee sake: woord van God en gebed. Wat verder opvallend is, is dat die genoemde uitspraak oor die wisselwerking tussen die spiritualiteit van die bedienaar en die gemeente gevolg word deur 'n metafoor (Stott, 1996: 116), naamlik dié van die atleet. Paulus se opdrag aan Timoteus is dan: "Oefen jou liewer om in toewyding aan God te lewe". Hierdie bevel tot beoefening van persoonlike spiritualiteit word dan weer gevolg deur 'n sentraalstelling van die woord in vers 9: "Dit is 'n betroubare woord en kan sonder voorbehoud aanvaar word". Ook in vers 11 word die aksie van woordhantering in twee imperatiewe uitgedruk: "Hierdie dinge moet jy die mense leer en beveel ...". In vers 13 word die aksies uit die Woord weer beklemtoon in "totdat ek kom, moet jy jou daarop toelê om uit die Skrif voor te lees, te preek, en onderrig te gee".

Vir die behandeling van die tema van die spiritualiteit van die bedienaar in sy toerusting bied die breër verband van vers ses belangrike lig: die aksies van Skrifhantering en van gebed staan naamlik sentraal in die opdrag aan die bedienaar om ware spiritualiteit met God te beoefen.

\section{- Selfvoeding en gemeentevoeding as toerusting}

Wat in die lig van bostaande beredenering nou aandag behoort te ontvang, is die uitdrukking in vers 6 "... aan die broers voorhou ..." en "... jouself voed met die woorde van geloof en die goeie leer". Hier word in Grieks twee praesens partisipia feitlik in een sin gebruik, naamlik hupotithemos (voorhou) en entrephomenos (voed). Hierdie gebruik van die twee praesens partisipia hou in dat die een aksie nie noodwendig (chronologies) volg op die ander aksie nie. Voed volg nie op voorhou of andersom nie. Voorhou en voed staan eerder in voortdurende wisselwerking met mekaar. Dus: terwyl die bedienaar die Woord aan die gemeente voorhou (= hulle toerus), voed hy homself (= rus hy homself toe), maar ook: hy sal net en alleenlik die Woord aan die gemeente kan voorhou as hy homself voortdurend uit die Woord voed!

Hierdie vasstelling moet as kardinaal beskou word vir die verband tussen die spiritualiteit van die bedienaar en die spiritualiteit van die gemeente. 
Die volgende afleidings kan uit hierdie uiteensetting gemaak word:

- Daar is 'n direkte korrelasie of verband tussen die spiritualiteit van die bedienaar en van die gemeente. Konkreet kan wat hier geformuleer is, moontlik soos volg gestel word: 'n bedienaar kan van die gemeente nie 'n dieper vlak van spiritualiteit verwag as wat sy eie is nie.

- Die spiritualiteit van die bedienaar en van die gemeente hang onlosmaaklik saam met die persoonlike omgang van die bedienaar met die Woord (selfvoeding). Ook hang sy spiritualiteit saam met sy deurgee (voorhou) van die Woord wat hy sy eie gemaak het as toerusting aan die gemeente. Die voorhou van die Woord aan die gemeente hou in dat hyself eers die Woord "verteer en opgeneem" het in sy sisteem sodat hy die Woord oortuigend met die oog op voeding van die gemeente kan voorhou. Dié voorhou van die Woord begin dus by die bedienaar se eie, persoonlike beoefening van spiritualiteit - en juis dit stempel hom tot "'n goeie bedienaar van Jesus Christus" (vers 6b).

\section{- Die beoefening van spiritualiteit as samevatting van die wisselwerking tussen selfvoeding en gemeentevoeding}

In 1 Timoteus 4:7 word die teenoorgestelde van die aksie van selfvoeding en gemeentevoeding gestel as: besig wees met onheilige en sinlose verdigsels (letterlik ouvroupraatjies) wat deur Timoteus vermy moet word. Dié uitspraak word direk gevolg deur die oproep tot beoefening van spiritualiteit in vers 8 : "Oefen jou liewer om in toewyding (eusebeia) aan God te lewe. Om jou liggaam te oefen het wel 'n bietjie waarde, maar om in toewyding (eusebeia) aan God te lewe het in alle opsigte groot waarde, want dit bevat die belofte vir nou en die toekoms".

Vanuit die aanduiding van spiritualiteit in die Pastorale Briewe veronderstel hierdie toewyding aan God die versoeningswerk van Christus en die opregtheid van die bedienaar.

Wat verder in 1 Timoteus 4:7-8 opvallend is, is die twee maal herhaalde patroon in die gebruik van die voorsetsel pros in hierdie verse. Die voortdurende oefening in spiritualiteit moet (letterlik) wees tot toewyding en die toewyding het weer waarde tot baie dinge. Die herhaalde voorkoms van die voorsetsel pros het die nuanse van: oefen jouself tot op die punt van toewyding (i.c. spiritualiteit) en voorts: kom in jou toewyding tot op 'n bepaalde punt (van fiksheid). Kyk dan net na die voordele. Hierdie toewyding berei jou voor om nou in die huidige te leef - en in die ewige lewe. Toewyding aan God as oefening in spiritualiteit is ' $n$ dimensie wat vanuit die huidige (onvolmaakte) bedeling deurloop tot in die ewige lewe (die volmaakte bedeling). 


\section{Gebed en die spiritualiteit van die bedienaar}

In die behandeling van die begrip spiritualiteit in die Pastorale Briewe en uit die aanduiding van die wisselwerking tussen die spiritualiteit van die bedienaar en die spiritualiteit van die gemeente, is twee sentrale aksies in verband met spiritualiteit uitgelig en beklemtoon: die aksie van gebed en die aksie van omgang met die Woord. Wat nou eerstens in vooruitsig gestel word, is 'n nadere ontginning van die Pastorale Briewe en Efesiërs oor gegewens in verband met die gebed en spiritualiteit in die lewe van die bedienaar en in sy werk om toe te rus.

\section{- 1 Timoteus 2:1 en 2}

In hierdie verse word die gemeente opgeroep om te bid vir mense in gesagsposisies. Wat eerstens opvallend is, is die verskeidenheid gebede. Smeking, voorbidding, danksegging moet vir alle mense, veral vir hooggeplaastes gedoen word. Dat sodanige gebede vir alle mense gedoen moet word, wys onder andere op die individualiserende aard van die gebede: vir alle mense volgens elkeen se behoefte.

Wat egter vir ons doel van belang is, is die doel van die gebede. Die doel word in vers 2 aangedui as “... sodat ons 'n rustige en stil lewe kan lei in volkome toewyding (eusebeia) aan God ...". Die gebed vir regeerders (i.c. die staat) is dus gerig op die uiteindelike doelwit dat elkeen sy persoonlike spiritualiteit voor God kan beoefen. Met hierdie gebed word die staat in God se hande geplaas en die staatsmag aan God se mag ondergeskik gestel (Johnson, 1996:130), juis sodat gelowiges groei in hulle toewyding aan God (Grenz, 1988:66) onder andere deur hulle gedrag as burgers van die staat (Bassler, 1996:51).

As samevatting van hierdie opdrag om te bid, vervolg Paulus dan in vers 8 dat die mans "heilige hande" moet ophef ... en vry van onmin en twis moet bid. "Heilige hande" kan hier inhou: met 'n skoon gewete, maar hou veral in 'n gesindheid van gewillig en begerig wees om jou voor God te stel (Roloff, 1988:131).

'n Bepalende aspek wat hier gestel moet word, is dat gebid moet word, "vry van onmin en twis". Die uitdrukking "vry van onmin en twis" vind inhoudelik weerklank in 1 Timoteus 3:3 waar onder andere as vereiste aan die bedienaar gestel word dat hy nie 'n rusiemaker moet wees nie. Rusie en gebed (en dus rusie en ware spiritualiteit) is voor God onversoenbaar, sowel in die lewe van die bedienaar as in die lewe van 'n gemeente.

\section{- 2 Timoteus 1:3 (c) en 5 (a) - 'n skoon gewete en 'n opregte geloof}

In hierdie verse word Paulus se gebed en die diepste vlak van Timoteus se spiritualiteit (sy opregte geloof) met mekaar verbind. 
As Paulus stel dat hy God dank wanneer “... ek onophoudelik dag en nag in my gebede aan jou dink", hou dit nie in dat Paulus voortdurend in gebed is en nooit ophou bid vir Timoteus nie. Die uitdrukking hou wel in dat wanneer Paulus ook al aan Timoteus dink, hy (Paulus) dan wel vir hom bid, met ander woorde by elke gebedsgeleentheid "in the sense of a frequent repetition" (Lea \& Griffin, 1992:184; vgl. Minor, 1992:11). In sy gebed dink (of herinner) Paulus (hom) nie net aan Timoteus (self) nie, hy roep ook Timoteus se ongeveinsde geloof in sy gebed in herinnering. Hiermee verbind Paulus sy eie gebed aan die sentrale leitmotiv in Timoteus se spiritualiteit, naamlik Timoteus se opregte geloof. Dit is opvallend dat as Paulus praat van sy eie diens aan God (sy spiritualiteit!) dan sê hy dat hy God met 'n skoon gewete dien en as hy vir Timoteus bid, dank hy vir Timoteus se opregte geloof. 'n Skoon gewete en 'n opregte geloof is die diepste innerlike openbaring van spiritualiteit. En die feit dat bedienaars God dank vir wat hulle van 'n suiwer spiritualiteit in mekaar waarneem, is die diepste uiterlike openbaring van egte spiritualiteit.

\section{- 2 Timoteus 2:22}

In hierdie vers word twee opdragte aan Timoteus gerig, die eerste negatief en die tweede positief. Timoteus moet wegvlug van die begeertes wat 'n jong mens in gevaar bring. Positief moet hy in gebed in gemeenskap met sy medegelowiges (= almal wat die Here aanroep) sekere onderskeidende uitinge van spiritualiteit, "the four marks of a Christian" (Stott, 1973:73-74) najaag. Hierdie vier elemente, naamlik regverdigheid (opregtheid), geloof, liefde en vrede kan beskou word as die kernmanifestasie van spiritualiteit van gelowiges wat God in hulle gebede met 'n rein hart saam aanroep.

\section{- Efesiërs 6:19-20}

Die direkte konteks van hierdie verse is die uiteensetting van die wapenrusting van die gelowige. Hierdie wapenrusting moet biddend en smekend gehanteer word. Daarom moet die gemeente bid vir al die gelowiges. Hierna volg: "Bid ook vir my dat wanneer ek preek God my die woorde gee dat ek met vrymoedigheid die geheimenis van die evangelie kan bekend maak".

Ons het hier 'n klassieke voorbeeld van die gebed van 'n gemeente vir 'n bedienaar. Met hierdie afsluitingsgebed in Efesiërs gryp Paulus as't ware terug op die inleidingsgebed in Efesiërs 1:15-23. Hier het hy as bedienaar vir die gemeente gebid "... dat die God van ons Here Jesus Christus ... deur sy Gees aan julle wysheid gee en Hom so aan julle openbaar dat julle Hom werklik kan ken" (1:17). In die slotgebed vra hy die gemeente om vir hom, 'n dienskneg in boeie, te bid met die doel dat hy die geheimenis van die evangelie met vrymoedigheid bekend kan maak.

Dit is duidelik dat die gebed van die gemeente vir die bedienaar volgens Efesiërs 6:19-20 'n dubbele gerigtheid behoort te hê: enersyds op die geheimenis van die 
evangelie en andersyds op die vrymoedigheid van die bedienaar om die geheimenis bekend te maak. Geheimenis moet hier nie verstaan word as 'n geheimsinnige saak nie, maar as 'n saak wat lank verborge was, maar nou (uiteindelik) geopenbaar is, ten diepste in Jesus Christus. Krämer (1991:449) toon aan dat die begrip musterion basies aandui "that which is unspeakable, i.e. inaccessable to natural reason but accessible to faith". Die ontvouing van hierdie geheimenis in die prediking is daarom 'n saak van gebed en geloof (vgl. Peterson, 1989:72-74; 1987:44-58).

Die aandag moet ook gevestig word op die feit dat die gebed van die gemeente gerig moet wees op die vrymoedigheid (parresia) van die bedienaar om te kan preek. In die sekulêr Griekse spraakgebruik het hierdie uitdrukking die reg van 'n burger aangedui om sy sê te sê (= alles te sê wat hy op die hart het) as hy praat tydens 'n politieke vergadering (Balz, 1993:45). Toegepas op Paulus se prediking, hou die begrip vrymoedigheid in om vreesloos en openlik met vertroue die Woord te verkondig - al is hy geboei.

As samevatting van hierdie onderafdeling, word die volgende nou gestel:

- Vir die staat moet gebid word sodat elke gelowige sy spiritualiteit in rus kan beoefen.

- Onmin en twis staan in die weg van die ware gebed om spiritualiteit.

- 'n Opregte geloof en 'n skoon gewete as voorwaardes vir gebed is die diepste innerlike openbaring van ware spiritualiteit.

- Die kernmanifestasie van 'n lewe in toewyding aan God is opregtheid, geloof, liefde en vrede. Dit word gevind by mense wat God met 'n rein hart aanroep.

- Die gebed van die gemeente vir die bedienaar moet gerig wees op sy prediking en op sy vrymoedigheid om vreesloos met vertroue en openlik die geheimenisse van God bekend te maak. Die gebed van die gemeente is dus indirek 'n gebed om toegerus te word deur die bediening van die Woord.

\section{Omgang met die Woord en die spiritualiteit van die bedienaar}

In die Pastorale Briewe kan minstens agt Woordbedieningsbegrippe onderskei word (Kim, 1997:27). Hierdie bepaalde onderafdeling sal veral fokus op 'n nadere aanduiding van die Woord en wat die Woord teweegbring in die lewe van die bedienaar coram Deo en in sy toewyding met die oog op toerusting (vgl. Peterson, 1987:61-73). 
- 1 Timoteus 1:15-15

\section{Oorvloedige genade vir die grootste sondaar}

Hierdie gedeelte begin met die uitspraak: "Dit is 'n betroubare Woord ..." In hierdie telkens herhaalde uitspraak in die Pastorale Briewe word die kern van die evangelie saamgevat. Hierdie samevatting van die evangelie is waar en geloofwaardig. Dit kan dus gestel word dat ons hier te doen het met die inhoud en werking van die Woord in die geloofslewe van Paulus as bedienaar van Jesus Christus (vgl. Stott, 1996:52; Lea \& Griffin, 1992:74). Van hierdie inhoud van die evangelie is die kern weer: "Christus Jesus het in die wêreld gekom om sondaars te verlos ...". Die aoristustyd dui hier aan: om vir eens en vir altyd, finaal te verlos. Dit is veelseggend dat Paulus hier as't ware spring van die kom van die evangelie na sy eie situasie: Christus het sondaars kom red "... van wie $e k$ die grootste is". Letterlik staan hier: van wie ek die eerste is, die een wat (as leier) voor in die ry staan (protos). Aan hom wat as sondaar voor in die ry staan, betoon Christus al sy verdraagsaamheid. In hierdie gedeelte is 'n woordspeling tussen protos (16b) as die grootste sondaar aan wie God al sy verdraagsaamheid betoon het. Die oortreffende uitsprake is opvallend hier: grootste sondaar ontvang as grootste sondaar alle verdraagsaamheid.

Met hierdie uitspraak word van die diepste wortels in die spiritualiteit van die bedienaar blootgelê, naamlik die belydenis uit die Woord dat hyself 'n sondaar is, dat hy selfs die grootste van alle sondaars mag wees, maar dat hyself genade (eleos) van 'n koning ontvang het.

In vers 14 word die meedeel van hierdie genade beskryf as "oorvloedig" soos 'n rivier wat sy walle oorstroom (Stott, 1996:52). Die voorwaarde vir die toewyding van die bedienaar aan God is kennis van sy sonde en ellende, en dit impliseer "... the language of every sinner whose conscience has been awakened and disturbed by the Holy Spirit" (Stott, 1996:53). Paterson (1997:21) stel dit so: "... genuine spirituality consists in a re-discover of the cohesive and comprehensive nature of the grace of God in the life of a believer".

Op grond van die betroubare Woord en deur die werking van die Gees is ' $n$ bedienaar eers as begenadigde sondaar ' $n$ kind van God en pas dan bedienaar van die Woord. Tot op hierdie punt word hy gebring deur "die betroubare Woord".

\section{- 1 Timoteus 4:13-16}

\section{Groei in spiritualiteit}

In vers 13 is sprake van verskillende aksies van Woordbediening: Timoteus moet aanhou om uit die Skrif voor te lees, te preek en te onderrig.

Hierna roep Paulus Timoteus op om nie die genadegawe wat aan hom gegee is, te verwaarloos nie. Hierdie genadegawe (charismata) is aan Timoteus gegee met 
en onder die handoplegging van die onderlingekorps. Hierdie mededeling word dan gevolg deur 'n oproep tot voortgaande groei in Timoteus se spiritualiteit.

In vers 15 word Timoteus beveel: "Lê jou op hierdie dinge toe, leef daarin, sodat almal jou vordering kan sien".

Timoteus moet sekerlik - maar nie uitsluitlik nie - daarop let om nie die genadegawe wat hy het te verwaarloos nie. (Hy moet eerder lewe in die vuur blaas wat sy ampsgawe betref.)

Tog kan hierdie genadegawe nie los gesien word van die verskillende opdragte om die Woord te bedien nie (voorlees, preek, onderrig - vers 13). Die konsekwensie is dat die nie-verwaarloos van die genadegawe vir die gemeente duidelik sal word uit die verskillende dimensies van Timoteus se Woordbediening. Daarom: "let op hierdie dinge" (meleta - dieselfde stam sit in die Griekse werkwoord "verwaarloos"). In "hierdie dinge" moet Timoteus leef. Letterlik staan daar: "in hierdie dinge moet jy wees". Soos wat die inasem van vars lug wesenseie aan 'n mens is, so is die "wees" in hierdie dinge wesenseie vir die bedienaar en vir die voortgang van sy spiritualiteit. Wat meer is, die voortgang in spiritualiteit moet sigbaar wees vir "almal", dit wil sê vir gemeente en buitestanders (Schucksmith, 1998:152).

Met die beredenering hierbo het ons weer gekom by 'n kerndimensie in die bedienaar se spiritualiteit: die groei en voortgang daarin. Groei is onlosmaaklik verbind aan die hantering van die Woord. En ironies: die gebrek aan groei word ook eerste raakgesien in die wyse waarop die bedienaar die Woord in sy eie lewe hanteer, en in die gemeente! As 'n bedienaar nie groei in spiritualiteit nie, kan hy die gemeente nie toerus nie, want hy het gestagneer in sy geloofslewe!

Om hierdie rede is dit dan ook natuurlik dat die opdrag dat groei in spiritualiteit sigbaar moet wees, gevolg word deur: "Let op jouself en jou leer ...". In die lewe van die bedienaar gaan die sorg vir en die groei in persoonlike spiritualiteit die ander dimensies van sy ampswerk vooraf.

'n Verdere aspek kom na vore in die opdrag: "Let op jouself ..." en dit is die aspek van selfondersoek as 'n wesensdeel van die bedienaar se spiritualiteit. Selfondersoek moet in hierdie sin van die Woord nie as sieklike, selfgerigte introspeksie beskou word nie, maar as 'n middel tot voortgaande geestelike groei. "Self-criticism involves the knowledge of God first and then the knowledge of the self in the light of God's revelation" (Miller, 1997:333). Selfondersoek hou in dat 'n pastor homself sien soos God hom sien, en om homself te ken soos hy deur God geken word. Sonder gereelde selfondersoek, berou en terugkeer na God, staan ook die bedienaar - as sondige mens - oop vir selfmisleiding deur sy sondige hart.

As samevatting van hierdie onderafdeling kan die volgende gestel word: 
- Ware spiritualiteit hou in dat die bedienaar eers begenadigde kind van God is en dan bedienaar.

- Groei in spiritualiteit hang nou saam met die bedienaar se omgang met die Woord.

- Groei in spiritualiteit by die bedienaar moet sigbaar wees vir die gemeente.

- As 'n bedienaar in sy spiritualiteit stagneer, kan hy die gemeente nie toerus nie.

- 'n Wesensdeel van die bedienaar se spiritualiteit is gereelde selfondersoek.

\section{Finale samevatting}

Die doel van hierdie artikel is in die inleiding omskryf as ' $n$ poging om - in besonder vanuit die Pastorale Briewe - materiaal te ontgin met die oog op die vorming van basisteorieë vir die Praktiese Teologie oor die onderwerp: bedienaar en spiritualiteit met verwysing na sy toerustingstaak.

As finale samevatting kan die hoofresultate van hierdie ondersoek soos volg geformuleer word:

- Spiritualiteit word in die Pastorale Briewe omskryf in die kernbegrippe eusebeia (godsvrug, toewyding), hagneia (suiwerheid) en hagios (afsondering en toewyding) aan God.

- Die spiritualiteit van die bedienaar moet pneumatologies gefundeer en beoefen word.

- Daar is 'n wisselwerking tussen die spiritualiteit van die bedienaar en dié van die gemeente.

- Die beoefening van spiritualiteit deur die bedienaar en gemeente vind plaas deur voeding daarvan uit die Woord.

- Persoonlike gebed - en gebed deur die gemeente vir die bedienaar - saam met selfondersoek, verdieping en meditasie van die Woord, is vier kernelemente in die beoefening van en groei in die spiritualiteit van die bedienaar.

- Groei in die bedienaar se spiritualiteit moet deur die gemeente gesien word.

- Gebrek aan groei in die spiritualiteit van die bedienaar werk remmend in op die toerusting van die gemeente tot geestelike groei. 


\section{Bibliografie}

BAIR, M.J. 1995. The postmodern phenomena of New Age spirituality: examples in popular literature. Ashland Theological Journal, 27:54-82.

BALZ, H. 1990. Hagios. (In Balz, H. \& Schneider, G., eds. Exegetical dictionary of the New Testament I. Grand Rapids : Eerdmans. p. 16-22.)

BALZ, H. 1993. Parresia. (In Balz, H. \& Schneider, G., eds. Exegetical dictionary of the New Testament III. Grand Rapids : Eerdmans. p. 45-47.)

BARTHOLOMEW, C. 1998. Reading the Old Testament in postmodern times. Tyndale Bulletin, 49(1):91-114.

BASSLER, J.M. 1996. 1 Timothy, 2 Timothy, Titus. Nashville : Abingdon.

BRINK, E.R. 1997. Trends in Christian and Reformed worship. Calvin Theological Journal, 32(2):395-406.

CLEMENTS, R. 1998. Expository preaching in a postmodern world. Foundations, 40:10-17.

DRANE, J.W. 1997. Christian responses to the New Age spirituality. Evangelical Review of Theology, 21(4):332-340.

FIEDLER, F. 1991. Eusebeia, eusebeõ eusebõs. (In Balz, H. \& Schneider, G., eds. Exegetical dictionary of the New Testament II. Grand Rapids : Eerdmans. p. 84-85.)

GRENZ, S.J. 1988. Prayer: the cry for the kingdom. Massachusetts : Hendrickson.

HOUSTON, J.M. 1991. Spiritual life today: an appropriate spirituality for a post-modern world. (In Eden, M. \& Wells, D.F., eds. The Gospel in the modern world. A tribute to John Stott. Leicester : Inter-Varsity. p. 179-197.)

HULSE, E. 1986. The preacher and piety. (In Logan, S.T., ed. The preacher and preaching. Reviving the art in the twentieth century. New Jersey : Presbyterian and Reformed Publishing Company. p. 62-90.)

JOHNSON, L.K. 1996. Letters to Paul's delegates. 1 Timothy, 2 Timothy, Titus. Pennsylvania : Trinity.

KANAGARAJ, J.J. 1997. The involvement of the laity in the ministry of the church. Evangelical Review of Theology, 21(4):326-331.

KIM, H.K. 1997. Preacher and spirituality. A diaconiological study in the light of the Pastoral Epistles. Potchefstroom : PU for CHE. (Th.M.-dissertation.)

KRäMER, H. 1991. Musterion. (In Balz, H. \& Schneider, G., eds. Exegetical dictionary of the New Testament II. Grand Rapids : Eerdmans. p. 446-449.)

LARTEY, E.Y. 1997. In living color. An intercultural approach to pastoral care and counselling. London : Cassel.

LEA, T.D. \& GRIFFIN, H.P. (jnr). 1992. A new American commentary, vol. 34.

1, 2 Timothy, Titus. Nashville : Broadman.

LEITHART, P. 1997. Transforming worship. Foundations, 38:27-34.

LOUW, D.J. 1997. 'n Diagnostiese model vir die assessering van spiritualiteit met die oog op geloofsontwikkeling in die pastorale bediening. Praktiese Teologie in Suid-Afrika, 12(2):11-25.

MILLER, P. 1997. Spirituality, integrity and competence: essentials of ministry in Richard Baxter's Reformed Pastor. The Evangelical Quarterly and International Review of Bible and Theology, 69(4):333-342.

MINOR, E.E. 1992. An exegetical summary of 2 Timothy. Dallas : Summer Institute of Linguistics.

NEL, M. 1994. Gemeentebou. Halfway House : Orion.

OH, J.H. 1998. Disciple-making preaching in the light of the New Testament: an exegetic-homiletical study. Potchefstroom : PU vir CHO. (Th.D. thesis.)

PATERSON, A. 1997. A spirituality of Word and Spirit for a post-modern world. Foundations, 39:21-24.

PERKINS, P. 1997. Ephesians. Nashville : Abingdon. 
PETERSON, E.N. 1987. Working the angles. Grand Rapids : Eerdmans.

PETERSON, E.N. 1989. Thew contemplative pastor. Grand Rapids : Eerdmans.

ROLOFF, J. 1988. Der erste Brief an Timotheus. Zurich : Benziger.

SCHUCKSMITH, B. 1998. The pastor's self-care. Churchman, 112(2):150-162.

STOTT, J.R.W. 1967. The preacher's portrait. London : Tyndale House.

STOTT, J.R.W. 1973. The message of 2 Timothy. Leicester : Inter-Varsity.

STOTT, J.R.W. 1996. The message of 1 Timothy and Titus. Leicester : Inter-Varsity.

TIDBALL, D. 1997. Skilful shepherds. Explorations in pastoral theology. Leicester : Apollos.

VAN DER MERWE, M. 1995. Nuwe treë saam met God. Riglyne oor spiritualiteit en gemeentevernuwing. Kaapstad : Lux Verbi.

VELEMA, W.H. 1992. Geloof en gevoel. Leiden : Groen en Zoon.

VENTER, C.J.H. 1986. Gemeente-opbou in Hebreërs. Potchefstroom : PU vir CHO, Sentrale Publikasies.

VENTER, C.J.H. 1998. Spiritualiteit in Romeine 12. In die Skriflig, 32(4):457-468.

WITVLIET, J.D. 1997. The spirituality of the Psalter. Metrical Psalms in liturgy and life in Calvin's Geneva. Calvin Theological Journal, 32(2):273-297. 